\title{
Determining the Water Quality Index of an Urban Water Body Dal Lake, Kashmir, India
}

\author{
${ }^{1}$ Raj Shailesh Kanakiya, ${ }^{2}$ S.K.Singh, ${ }^{3}$ J.N.Sharma \\ 1-Research Scholar, Environmental Engineering Department Delhi Technological University, Delhi, India \\ 2-Professor \& Head, Environmental Engineering Department, Delhi, India \\ 3-J.N.Sharma,Supretendent Engineer, J\&K pollution Control Board, J\&K India
}

\begin{abstract}
A Water Quality Index (WQI) is a useful statistical tool for simplifying, reporting and interpreting complex information obtained for any water body. A simple number given by any WQI model explains the level of water contamination.A water quality index carried out for Dal lakebased on very important parameters can provide a simple indicator of water quality.The present study deals with the monitoring of variation of seasonal water quality index of Dal lake. The index is used to improve the comprehension of general water quality issues, communicates water quality status and illustrates the need for and the effectiveness of protective practices. It is found that in all cases the change in WQI value follow a similar trend throughout the study period. Water Quality Index of Dal lake for all four basinswere $(102.66,120.33,109.35,101.35)$ for all seasons summer, winter,monsoon thus it is found to be unfit for drinking.
\end{abstract}

Keywords: Dal lake, Water quality index, Water quality parameters

\section{Introduction}

Dal Lake is perceived as vast expanse of water in a pristine landscape where one goes forrecreation. It is a place of experiencing nature by way of boating, camping, fishing, swimming, bird watching, etc. however, when one mentions 'urban lakes' the picture is soon demystified. While urban lakes are different from the common perception of lakes in general they too have value and functions, both ecosystem functions and social values.

The word "Lake" is used loosely to describe many types of water bodies - natural, manmade and ephemeral including wetlands.

The biodiversity of lake and pond ecosystems is currently threatened by a number of human disturbances, of which the most important include increased nutrient load, contamination,acidification, and invasion of exotic species (Bronmark \& Hansson, 2002). The ecological stress of the system is reflected by deterioration of water quality and increased levels of biological productivity.

Hydrologic change is the most visible impact of urbanization. Hydrology concerns the quality, duration, rates, frequency and other properties of water flow. Urbanization typically increases runoff peak flows and total flow volumes and damages water quality and aesthetics. Pollutants reach wetlands mainly through runoff. Urbanized watersheds generate large amounts of contaminants, including eroded soil from construction sites, toxic metals and petroleum from roadways, industrial and commercial areas, and nutrients and bacteria from residential areas. By volume, sediment is the most important non-point pollutant. At the same time that urbanization produces large quantities of pollutants, it reduces water infiltration capacity, yielding more surface runoff. Pollutants from urban land uses are, therefore, more vulnerable to transport by surface runoff than pollutants from other land uses.

The organic and inorganic pollutant load in the Dal has accelerated the macrophytic growth which in turn has reduced the water quality and biological oxygen demand (BOD) of the lake and hence has reduced the recreational and aesthetic appeal of the lake

The chemistry of lake water and sediment is a cumulative reflection of catchment geology, weathering and erosional processes as well as anthropogenic inputs. The chemical degradation of silicate and carbonate minerals is various processes, such as dissolution, hydrolysis, oxidation, and reduction (Gupta and Subramanian, 1998).

The basic chemical reactions take place among silicates, carbonates, and rainwater,congruently or incongruently, gives rise to various ions and clay minerals (Freeze and Cherry, 1979).Being an urban type lake, municipal and domestic effluents have altered the surface water composition of Dal Lake, leading to increased eutrophication (Hutchinson, 1999). Moreover, excessive sedimentation rates enhanced by extensive soil erosion due to deforestation and an encroachment by surrounding population have dramatically reduced the lake volume (Chakrapani, 2002). The lake serves as a resource of drinking water, irrigation, fisheries, recreation, tourism, etc. 
A Water Quality Index (WQI) is a useful statistical tool for simplifying, reporting and interpreting complex information obtained from any body of water. A simple number given by any WQI model explains the level of water contamination.A water quality index based on some very important parameters can provide a simple indicator of water quality. In general, water quality indices incorporate data from multiple water quality parameters into a mathematical equation that rates the health of a waterbody with number.

\section{Study Area}

Dal Lake (Lat. $340-6^{\prime}$ N, 740-45' E, alt.1583m) situated in the heart of Srinagar city, the summer capital of Jammu Kashmir State is under tremendous anthropogenic pressure. The myriad is ways in which people use the lake along with the numerous pollutant generating activities have stressed the lake ecosystem in diverse ways.

\section{The lake is divided into four basins}

Hazratbal, Boddal, Nageen and Gagribal The lake is mainly fed by a large perennial inflow channel, Telbal nala, which drains the largest subcatchment area of about $145 \mathrm{~km}^{2}$ and contributes to about $80 \%$ of the total inflow to the lake (Zutshi and Vass 1978; Trisal 1987, Jellani 2006) as well as a number of small streams, viz,Peshpaw nala, Shalimar nala, Merakhsha nala, Harshikul,etc, around the shore line besides some contribution from groundwater. Within the lake basin itself there are number of springs (Kundangar et al., 1995) which act as permanent water source to the lake. The Nageen basin is the deepest basin (maximum depth of about $6 \mathrm{~m}$ ), and Gagribal basin the shallowest (maximum depth $2.5 \mathrm{~m}$ ). Of the total area of the lake, $4.1 \mathrm{~km}^{2}$ is under floating garden or cultivation, $1.51 \mathrm{~km}^{2}$ is submerged land and $2.25 \mathrm{~km}^{2}$ under marshy conditions.

\section{Materials And Methods}

The Survey of the lake and its catchment area is done to know the sampling locations/ sites in the six sub-basins of the lake. The Sampling Sites is shown in the map indicated below. Samples have been collected from these Sites and the Physico - Chemical Analysis is being done in the Boards Laboratory for 12 parameters which are pH, conductivity, Hardness, DO, BOD, TDS, Total Alkalinity, Nitrite, Sulphate ,Chlorides, Calcium, Magnesium.

Various physico-chemical parameters analyzed for water and sediment samples included those for $\mathrm{pH}$ (Digital pH meter DPH 504), Electrical conductivity (EC) (Digital EC meter DEM900). Total dissolved solid (TDS) was determined by oven dry method. Biological Oxygen Demand (BOD) was estimated by Azide modification of Winkler method. Total Alkalinity (TA) as $\mathrm{HCO}^{3-}$, Calcium $\left(\mathrm{Ca}^{2+}\right)$, Magnesium $\left(\mathrm{Mg}^{2+}\right)$ total hardness $(\mathrm{TH})$, Chloride $(\mathrm{Cl})$, was estimated by standard titrimetry. Sulphate $\left(\mathrm{SO}_{4}{ }^{2-}\right)$ by turbidometry, Nitrate $\left(\mathrm{NO}_{3}{ }^{2-}\right)$ by Brucine method all using HITACHI UV-VIS spectrophotometer.

Table.1 Description of the Sites

\begin{tabular}{|l|l|l|}
\hline Sr.No & Site & Description \\
\hline 1 & Bod-dal & Central Char Chinar \\
\hline 2 & Nageen Lake & Central part of Nageen Lake \\
\hline 3 & Hazratbal Lake & Near outlet of Hazratbal STP \\
\hline 4 & Gagribal Lake & Near Nehru Park \\
\hline
\end{tabular}




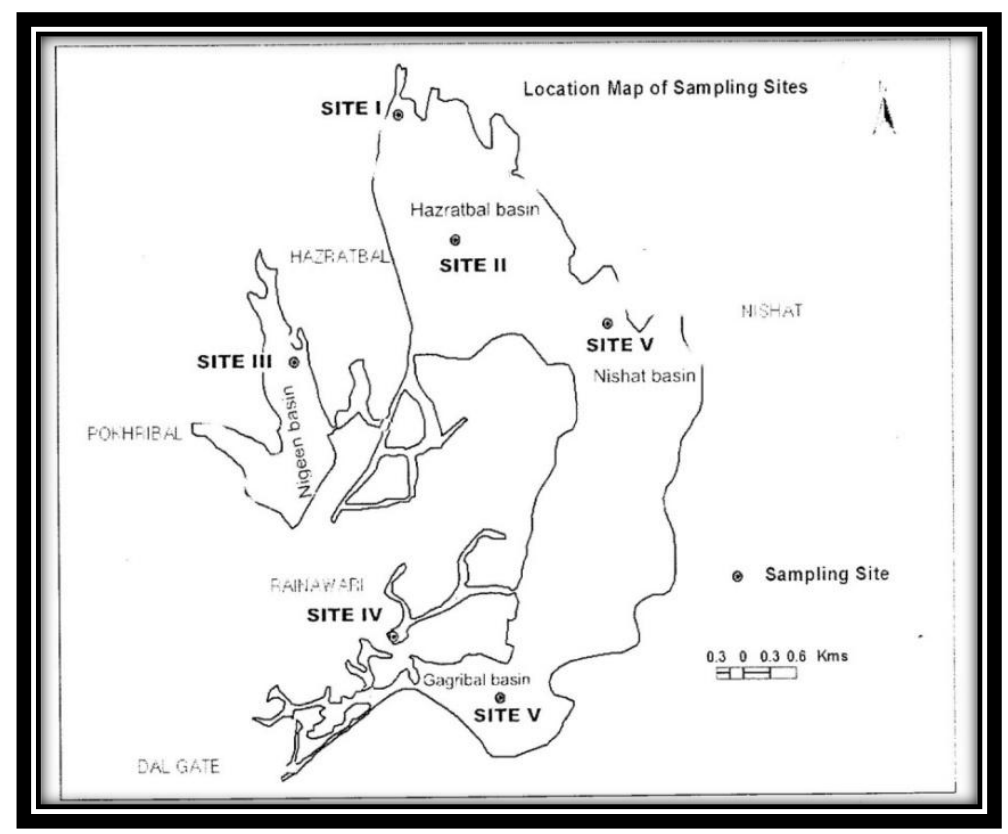

In this study, for the calculation of water quality index, twelve important parameters were chosen. The WQI used here are taken from as recommended by the standards of drinking water quality Bureau of Indian Standards (BIS) .

The weighted arithmetic index method (Brown et. al.,) has been used for the calculation of WQI of the waterbody. Further, quality rating or sub index (qn) was calculated using thefollowing expression.

\section{Qn= 100*[Vn -Vio $] /[$ Sn-Vio $]$}

(Let there be nwater quality parameters and quality rating or subindex (qn) corresponding to $\mathbf{n t h}$ parameter is a number reflecting the relative value of this parameter in the polluted water with respect to its standard permissible value.)

$\mathbf{q n}=$ Quality rating for the $\mathbf{n t h}$ Water quality parameter

$\mathbf{V n}=$ Estimated value of the $\mathbf{n t h}$ parameter at a given sampling station.

$\mathbf{S n}=$ Standard permissible value of the $\mathbf{n t h}$ parameter.

Vio= Ideal value of $\mathbf{n t h}$ parameter in pure water. (i.e., 0 for all other parameters except the parameter $\mathrm{pH}$ and Dissolved oxygen (7.0 and $14.6 \mathrm{mg} / \mathrm{L}$ respectively)

Unit weight was calculated by a value inversely proportional to the recommended standard value Snof the corresponding parameter.

\section{$\mathbf{W n}=\mathbf{K} / \mathrm{Sn}$}

$\mathbf{W n}=$ unit weight for the $\mathbf{n t h}$ parameters.

$\mathbf{S n}=$ Standard value for $\mathbf{n t h}$ parameters

$\mathbf{K}=$ Constant for proportionality.

The overall Water Quality Index was calculated by aggregating the quality rating with the unit weight linearly.

$\mathrm{WQI}=\Sigma \mathbf{q n W n} / \Sigma W n$

Table 2. Water Quality Index (WQI) and status of water quality

(Chatterji and Raziuddin2002)

\begin{tabular}{|l|l|l|}
\hline Sr.No & Water Quality Index & Water Quality Status \\
\hline 1 & $0-25$ & Excellent water quality \\
\hline 2 & $26-50$ & Good water quality \\
\hline 3 & $51-75$ & Poor water quality \\
\hline 4 & $76-100$ & Very Poor water quality \\
\hline 5 & $>100$ & Unsuitable for drinking \\
\hline
\end{tabular}

Table 3. Drinking Water standards recommending Agencies and unit weights. (All values except $\mathrm{pH}$ and Electrical Conductivity are in $\mathrm{mg} / \mathrm{L}$ )

\begin{tabular}{|l|l|l|l|}
\hline Sr.No & Parameters & Standard permissible value & Unit Weight \\
\hline 1 & $\mathrm{pH}$ & 8.5 & 0.2190 \\
\hline 2 & Electrical Conductivity & 300 & 0.371 \\
\hline 3 & Total Dissolved Solids & 500 & 0.0037 \\
\hline 4 & Total alkalinity & 120 & 0.0155 \\
\hline
\end{tabular}




\begin{tabular}{|l|l|l|l|}
\hline 5 & Total hardness & 300 & 0.0062 \\
\hline 6 & Calcium & 75 & 0.025 \\
\hline 7 & Magnesium & 30 & 0.061 \\
\hline 8 & Chlorides & 250 & 0.0074 \\
\hline 9 & Nitrate & 45 & 0.0412 \\
\hline 10 & Sulphate & 150 & 0.01236 \\
\hline 11 & Dissolved oxygen & 5 & 0.3723 \\
\hline 12 & Biological oxygen demand & 5 & 0.3723 \\
\hline
\end{tabular}

Table.No.4. Physico-chemical Characteristics of Sampling sites in all seasons

\begin{tabular}{|c|c|c|c|c|c|c|c|c|c|c|c|c|c|}
\hline Sr.No & Parameter & \multicolumn{2}{|c|}{ Central Char Chinar } & \multicolumn{3}{c|}{ Nageen Central } & \multicolumn{3}{c|}{ Hazratbal STP } & \multicolumn{3}{c|}{ Nehru Park } \\
\hline & & Feb & Jun & Jul & Feb & Jun & Jul & Feb & Jun & Jul & Feb & Jun & Jul \\
\hline 1 & $\mathrm{pH}$ & 8.20 & 8.40 & 8.40 & 8.10 & 8.20 & 8.70 & 7.50 & 7.90 & 8.20 & 7.40 & 8.00 & 8.20 \\
\hline 2 & Conductivity & 220.0 & 220.0 & 209.0 & 350.0 & 301.0 & 220.0 & 285.0 & 265.0 & 282.0 & 143.0 & 128.0 & 138.0 \\
\hline 3 & TDS & 143 & 116 & 152 & 192 & 192 & 149 & 184 & 198 & 201 & 83 & 85 & 91 \\
\hline 4 & T.Alkalinity & 160.0 & 212.0 & 225.0 & 190.0 & 309.0 & 235.0 & 225.0 & 218.0 & 256.0 & 68.0 & 76.0 & 70.0 \\
\hline 5 & T.Hardness & 392 & 112 & 142 & 228 & 126 & 120 & 366 & 156 & 184 & 268 & 82 & 104 \\
\hline 6 & Calcium & 36.00 & 37.00 & 36.00 & 38.00 & 40.00 & 39.00 & 38.00 & 43.00 & 42.00 & 45.69 & 22.40 & 21.64 \\
\hline 7 & Magnesium & 4.50 & 3.60 & 3.80 & 4.00 & 5.00 & 5.00 & 4.00 & 6.00 & 7.00 & 7.42 & 6.30 & 12.15 \\
\hline 8 & Chlorides & 12.0 & 15.0 & 16.0 & 20.0 & 18.0 & 18.0 & 17.0 & 21.0 & 24.0 & 21.0 & 16.0 & 12.0 \\
\hline 9 & Nitrates & 450 & 395 & 390 & 480 & 450 & 539 & 435 & 490 & 590 & 420 & 456 & 580 \\
\hline 10 & Sulphates & 11.0 & 7.0 & 12.0 & 9.0 & 19.0 & 16.0 & 16.0 & 14.0 & 18.0 & 4.35 & 11.7 & 19.20 \\
\hline 11 & DO & 6.8 & 6.5 & 6.8 & 5.4 & 5.5 & 5.0 & 6.0 & 5.8 & 5.5 & 4.3 & 6 & 4.3 \\
\hline 12 & BOD & 3.0 & 2.0 & 2.0 & 2.5 & 2.8 & 2.0 & 2.2 & 1.0 & 1.0 & 2.0 & 2 & 1.0 \\
\hline
\end{tabular}

Table.No.5 Calculation for Quality Rating

\begin{tabular}{|c|c|c|c|c|c|c|c|c|c|c|c|c|c|}
\hline Sr.No & Parameter & \multicolumn{2}{|c|}{ Central Char Chinar } & \multicolumn{3}{|c|}{ Nageen Central } & \multicolumn{3}{|c|}{ Hazratbal STP } & \multicolumn{3}{c|}{ Nehru Park } \\
\hline & & Feb & Jun & Jul & Feb & Jun & Jul & Feb & Jun & Jul & Feb & Jun & Jul \\
\hline 1 & $\mathrm{pH}$ & 80.0 & 93.3 & 93.3 & 73.3 & 80.0 & 113.3 & 33.3 & 60.0 & 80.0 & 26.7 & 66.7 & 80.0 \\
\hline 2 & Conductivity & 73.3 & 73.3 & 69.7 & 116.7 & 100.3 & 73.3 & 95.0 & 88.3 & 94.0 & 47.7 & 42.7 & 46.0 \\
\hline 3 & TDS & 28.6 & 23.2 & 30.4 & 38.4 & 38.4 & 29.8 & 36.8 & 39.6 & 40.2 & 16.6 & 17.0 & 18.2 \\
\hline 4 & T.Alkalinity & 133.3 & 176.7 & 187.5 & 158.3 & 257.5 & 195.8 & 187.5 & 181.7 & 213.3 & 56.7 & 63.3 & 58.3 \\
\hline 5 & T.Hardness & 130.7 & 37.3 & 47.3 & 76.0 & 42.0 & 40.0 & 122.0 & 52.0 & 61.3 & 89.3 & 27.3 & 34.7 \\
\hline 6 & Calcium & 48.0 & 49.3 & 48.0 & 50.7 & 53.3 & 52.0 & 50.7 & 57.3 & 56.0 & 60.9 & 29.9 & 28.9 \\
\hline 7 & Magnesium & 15.0 & 12.0 & 12.7 & 13.3 & 16.7 & 16.7 & 13.3 & 20.0 & 23.3 & 24.7 & 21.0 & 40.5 \\
\hline 8 & Chlorides & 4.8 & 6.0 & 6.4 & 8.0 & 7.2 & 7.2 & 6.8 & 8.4 & 9.6 & 8.4 & 6.4 & 4.8 \\
\hline 9 & Nitrates & 1000.0 & 877.8 & 866.7 & 1066.7 & 1000.0 & 1197.8 & 966.7 & 1088.9 & 1311.1 & 933.3 & 1013.3 & 1288.9 \\
\hline 10 & Sulphates & 7.3 & 4.7 & 8.0 & 6.0 & 12.7 & 10.7 & 10.7 & 9.3 & 12.0 & 2.9 & 7.8 & 12.8 \\
\hline 11 & DO & 156.0 & 162.0 & 156.0 & 184.0 & 182.0 & 192.0 & 172.0 & 176.0 & 182.0 & 206.0 & 172.0 & 206.0 \\
\hline 12 & BOD & 60.0 & 40.0 & 40.0 & 50.0 & 56.0 & 40.0 & 44.0 & 20.0 & 20.0 & 40.0 & 40.0 & 20.0 \\
\hline$\sum$ & Qn & 1737.1 & 1555.6 & 1566.0 & 1841.4 & 1846.1 & 1968.6 & 1738.8 & 1801.6 & 2102.9 & 1513.2 & 1507.4 & 1839.0 \\
\hline
\end{tabular}

Table.No.6 Formation of Water Quality Index

\begin{tabular}{|c|c|c|c|c|c|c|c|c|c|c|c|c|c|c|}
\hline Sr.No & Parameter & \multicolumn{1}{|c|}{ Central Char Chinar } & \multicolumn{3}{|c|}{ Nageen Central } & \multicolumn{3}{|c|}{ Hazratbal STP } & \multicolumn{3}{c|}{ Nehru Park } \\
\hline & & Feb & Jun & Jul & Feb & Jun & Jul & Feb & Jun & Jul & Feb & Jun & Jul \\
\hline 1 & pH & 17.52 & 20.44 & 20.44 & 16.06 & 17.52 & 24.82 & 7.30 & 13.14 & 17.52 & 5.84 & 14.60 & 17.52 \\
\hline 2 & Conductivity & 27.21 & 27.21 & 25.85 & 43.28 & 37.22 & 27.21 & 35.25 & 32.77 & 34.87 & 17.68 & 15.83 & 17.07 \\
\hline 3 & TDS & 0.11 & 0.09 & 0.11 & 0.14 & 0.14 & 0.11 & 0.14 & 0.15 & 0.15 & 0.06 & 0.06 & 0.07 \\
\hline 4 & T.Alkalinity & 2.07 & 2.74 & 2.91 & 2.45 & 3.99 & 3.04 & 2.91 & 2.82 & 3.31 & 0.88 & 0.98 & 0.90 \\
\hline 5 & T.Hardness & 0.81 & 0.23 & 0.29 & 0.47 & 0.26 & 0.25 & 0.76 & 0.32 & 0.38 & 0.55 & 0.17 & 0.21 \\
\hline 6 & Calcium & 1.20 & 1.23 & 1.20 & 1.27 & 1.33 & 1.30 & 1.27 & 1.43 & 1.40 & 1.52 & 0.75 & 0.72 \\
\hline 7 & Magnesium & 0.92 & 0.73 & 0.77 & 0.81 & 1.02 & 1.02 & 0.81 & 1.22 & 1.42 & 1.51 & 1.28 & 2.47 \\
\hline 8 & Chlorides & 0.04 & 0.04 & 0.05 & 0.06 & 0.05 & 0.05 & 0.05 & 0.06 & 0.07 & 0.06 & 0.05 & 0.04 \\
\hline 9 & Nitrates & 41.20 & 36.16 & 35.71 & 43.95 & 41.20 & 49.35 & 39.83 & 44.86 & 54.02 & 38.45 & 41.75 & 53.10 \\
\hline 10 & Sulphates & 0.91 & 0.58 & 0.99 & 0.74 & 1.57 & 1.32 & 1.32 & 1.15 & 1.48 & 0.36 & 0.96 & 1.58 \\
\hline 11 & DO & 58.08 & 60.31 & 58.08 & 68.50 & 67.76 & 71.48 & 64.04 & 65.52 & 67.76 & 76.69 & 64.04 & 76.69 \\
\hline 12 & BOD & 22.34 & 14.89 & 14.89 & 18.62 & 20.85 & 14.89 & 16.38 & 7.45 & 7.45 & 14.89 & 14.89 & 7.45 \\
\hline$\sum$ & WnQn & 172.38 & 164.66 & 161.28 & 196.36 & 192.91 & 194.83 & 170.04 & 170.90 & 189.83 & 158.51 & 155.36 & 177.82 \\
\hline$\sum$ & Wn & 1.62 & 1.62 & 1.62 & 1.62 & 1.62 & 1.62 & 1.62 & 1.62 & 1.62 & 1.62 & 1.62 & 1.62 \\
\hline & (WnQn)/Wn & 106.54 & 101.77 & 99.68 & 121.36 & 119.23 & 120.41 & 105.09 & 105.62 & 117.32 & 97.97 & 96.02 & 109.90
\end{tabular}

Graphical Representation of Seasonal Variation of Water Quality in Dal Lake 


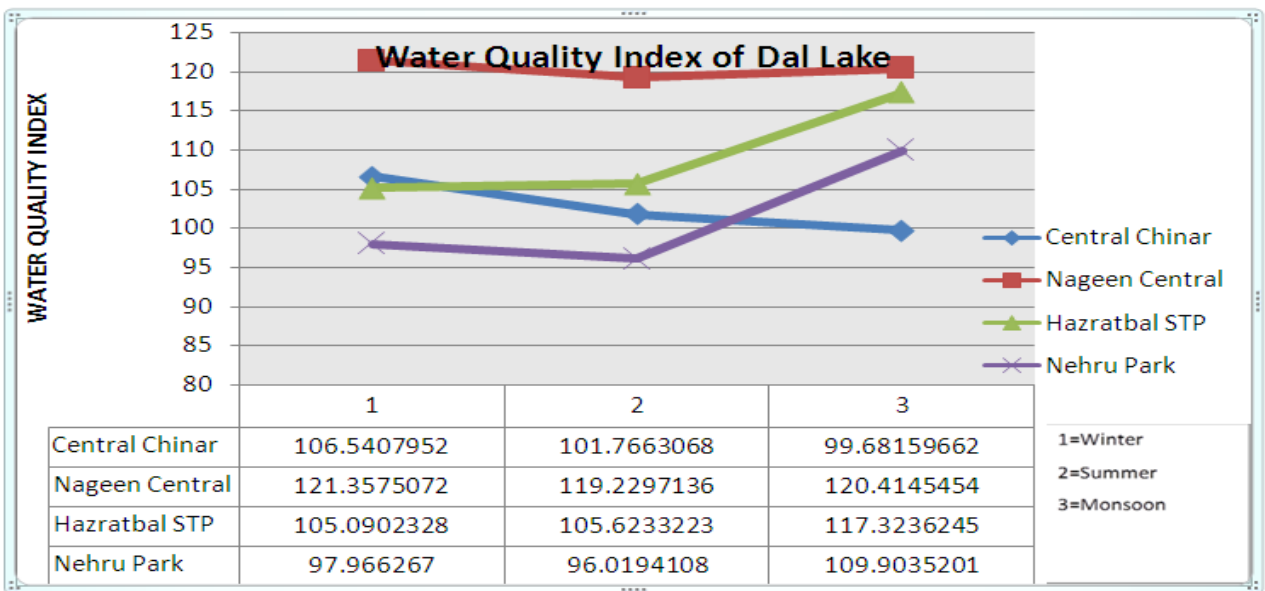

Table.No.8 Average Water Quality Index of Sampling Sites

\begin{tabular}{|l|l|l|}
\hline Sr.No & Sampling Site & Average Water Quality Index \\
\hline 1 & Central Chinar & 102.66 \\
\hline 2 & Nageen Central & 120.33 \\
\hline 3 & Hazratbal STP & 109.35 \\
\hline 4 & Nehru Park & 101.30 \\
\hline
\end{tabular}

\section{Results \&Discussion}

Water quality Index of the Dal lake is calculated for all seasons viz, rainy season, winter season and summer season. The values of various water related physico-chemical parameters for calculation of Water quality index are presented in Table 3 . Season wise

Water Quality Index calculations are depicted in the Table 5,6 and 7.

The Water Quality Index is calculated for four sites Char Chinar,NageenCentral,Hazratbal STP,i.e, are 102.66,120.33,109.35,101.3 respectivelyas per Table.No.8 thus it indicates the water unfit for drinking (Chatterji and Raziuddin 2002).

\section{PH}

Amongst the 12 parameters selected for forming Water Quality Index for Dal lake,

$\mathrm{pH}$ is an important parameter which determines the suitability of water for various purposes. In the present study $\mathrm{pH}$ ranged between $7.4 \& 8.7$. Overall average values for three seasons are taken into account the waterbody was found to be slightly alkaline in nature.(Ambasht (1971), Petre (1975), Shardendu and Ambasht (1988), have also made similar observations in their studies on different waterbodies.

\section{Conductivity}

Conductivity is a measure of capacity of substance or solution to conduct electric current. Conductivity determines the total dissolved solids in the water. Here,the range of Electro Conductivity is average for all other lakes except Nageen where it can be inferred that there the Conductivity is attributed to high salinity and high mineral content.

\section{Total Alkalinity}

According to BIS the maximum permissible limit is $120 \mathrm{mg} / \mathrm{L}$. The observed average value of total alkalinity was in greater in range of 160-390 mg/l except for Nehru Park in Gagribal basin. Totalalkalinity values in the study indicates that the water was very hard. Higher values of alkalinityregistered during summer might be due to the presence of excess of free $\mathrm{CO}_{2}$ product as a resultof decomposition process coupled with the mixing of sewage and domestic waste. The low alkalinityduring rainy season may be due to dilution. Jain et. al (1996) also reported similar finding in the study of the Halali Reservoir.

\section{Chloride}

Chloride is one of the most important parameter in assessing the water quality. Munawar (1970) is of the opinion that higher concentrations of chlorides indicate higher degree of organic pollution. In the present study the concentration of chloride fluctuated between $12 \mathrm{mg} / 1$ to $24 \mathrm{mg} / \mathrm{l}$.

\section{Nitrogen}

Nitrogen is an important nutrient for plant and algae growth in the lake. Nitrogen may enter a lake from surface runoff or groundwater sources. Sediments clearly cause nitrogen to undergo a number of changes. 
Nitrogen (rather than phosphorus) limits algae growth.The concentration of Nitrogen here is quite high in this study it is in range of $435 \mathrm{mg} / \mathrm{l}$ to $580 \mathrm{mg} / \mathrm{l}$.

\section{D.O and B.O.D}

The measurement of the DO is primary parameter in water pollution studies as it indicates aerobic or anaerobic nature of biological activities in water bodies (Trivedi, 1995).

The dissolved oxygen concentration depends on the physical, chemical and biochemical activities in the water body, and its measurement provides a good indication of water quality. The present study suggests that the concentration ofdissolved oxygen fluctuated between $4.3 \mathrm{mg} / 1$ and $5 \mathrm{mg} / 1$. Seasonally, the concentration of dissolved oxygen was more during monsoon and least during summer. Thus indicating variation of dissolved oxygen according to temperature and quantity of water supply This observation is in conformity with the observations of Reddy et.al., (1982)., Ghosh and George (1989), Swarnalatha and Narasingarao (1993) and Venkateswarlu (1993).Bio-chemical oxygen demand is a parameter to assess the organic load in a waterbody.

The BOD concentration ranged between $2 \mathrm{mg} / \mathrm{l}$ to $3 \mathrm{mg} / \mathrm{l}$ indicating the fact that the water body is eutrophic. Seasonally, it was high during summer, being in conformity with the observation of Chatterjee (1992).From all these foregoing observations of the physico-chemical parameters, it can be concluded that the water body shows the characters of eutrophication.

Low dissolved oxygen, high bio-chemical oxygen demand and high nitrate concentration this overall conditions indicate that highly eutrophic condition for the Dal lake.

\section{Calcium\& Magnesium}

The observed average value of calcium was in range of 22 to $40 \mathrm{mg} / \mathrm{l}$, which is below standard permissible limit of $75 \mathrm{mg} / \mathrm{l}$ prescribed by BIS. The quantities of calcium in natural water depends geology, types of rock present in the catchment.

While the observed average value of magnesium was in range of 4 to $12 \mathrm{mg} / 1$.Magnesium hardness particularly associated with the sulphate ion has laxative effect on persons unaccustomed to it (Khursid, 1998).

\section{Sulphate}

Sulphate in lake water is primarily related to the types of minerals found in the watershed and to acid rain. Industries and utilities that burn coal release sulphur compounds into the atmosphere that are carried into lakes by rainfall. In water depleted of oxygen (anaerobic water), sulphate can be reduced to hydrogen sulphide $\left(\mathrm{H}_{2} \mathrm{~S}\right)$.The range of Sulphate is $4.35 \mathrm{mg} / \mathrm{l}$ to $19.2 \mathrm{mg} / \mathrm{l}$.

\section{Algal Bloom}

In Dal lake the with the advent of time and due to increased and unabated human incursions within and lake peripheries have witnessed frequent algal blooms. Recurrence of such blooms has become a regular phenomenon in the various basins of the lake. A close relationship was observed between chloride and nitrates which almost coincided with those of high euglenoid population. The reason behind algal bloom can be inferred as lack of water flushing,enrichment of nutrient and building up of free carbon dioxide were the possible causes of the euglenoid bloom in Dal lake.

\section{Hardness}

Hardness in Dal Lake is higher than permissibleHardness concentration of freshwater bodies of Kashmir Valley has been associated with thick population of plankton, especiallyCyanophyceae (Bhat and Pandit, 2003).In this study in range is 300 to $400 \mathrm{mg} / \mathrm{l}$ in certain time of year. The values of total hardness are much fluctuating from that of summer months to winter months

\section{Conclusion}

At the outset, the study clearly indicates that the lake water is not fit for drinking consumption .It shall undergo treatment for it to be used for drinking purpose . Thus through Water Quality Index (WQI) we can have overall judgement whether that what purpose does the lake water suffice. In this method we use more systematic approach which gives comparative evaluation of the water quality of sampling stations within a water body. Water Quality index is helpful for public to understand the quality of water as well as being a useful tool in many ways in the field of water quality management.

These results are important so that the local authorities may implement preventive measures to reduce the threat of domestic and industrial discharges as well as agricultural activities discharges and have a check over the land use pattern in the Dal catchment. 


\section{References}

[1]. Ambasht, R.S., 1971. Ecosystem study of a tropical pond in relation to primary production of different vegetation zones. Hydrobiologia12 : 57-61.

[2]. BIS 1983. Standards for Water for Drinking and other purposes, Bureau of Indian Standards, New Delhi.

[3]. Bhat SA, Pandit AK (2003). Phytoplankton Dynamics in Anchar Lake,Kashmir. J. Res. Dev. 3:71-96

[4]. Brönmark C, Hansson L-A (2002) Environmental issues in lakes and ponds: current state and perspectives. Environmental Conservation

[5]. Brown, R.M., McCleiland, N.J., Deininger, R.A. and O’Connor, M.F. (1972): A Water Quality Index - Crossing the Psychological Barrier (Jenkis, S.H., ed.) Proc. Int. Conf. on Water Poll. Res., Jerusalem, Vol.6, pp.787-797.

[6]. Chakrapani GJ (2002) Water and sediment geochemistry of major Kumaun Himalayan lakes, India. Environ Geol 43, $99-107$.

[7]. Chatterjee, A.A., 1992. Water quality of Nandakananlake. India., J. Environ. Hlth. 34(4): 329-333.

[8]. Chaterjee,C. and Raziuddin, M.2002. Determination of water quality index (WQI) of a degraded river in Asanol Industrial area, Raniganj, Burdwan, West Bengal. Nature, Environment and pollutionTechnology,1(2):181-189.

[9]. Gupta LP and Subramanian V (1998) Geochemical factors controlling the chemical nature of water and sediments in the Gomtiriver. India Env. Geol. 36 (1-2), 102-108

[10]. Ghosh, A. and J.P. George, 1989. Studies on the abiotic factors and zooplakton in a polluted urban reservoir HussainSagar, Hyderabad: Impact on water quality and Embryonic Development of Fishes. Indian J.Environ.H1th. 31(1): 49-59

[11]. Hutchinson G. E., A Treatise on Limnology, Vol. II, Introduction to Lake Biology and the Limnoplankton, John Wiley and Sons, Inc. New York (1967)

[12]. Freeze, R.A., and Cherry, J.A., 1979, Groundwater: Englewood Cliffs, NJ, Prentice-Hall, 604 p.

[13]. Jain S. M., Meenakshi Sharma and Ramesh Thakur. Seasonal variation in Physico-chemical parameters of Halali reservoir of Vidisha district, Indian Journal of Ecobiology8:3, 81 - 188 (1996).

[14]. Jeelani, G, Shah AQ (2006) Geochemical characteristics of water and sediment from the Dal Lake, Kashmir Himalaya: constraints on weathering and anthropogenic activity. Environ Geol. 50, 12-23.

[15]. Khursid. S, Zaheeruddin and A. Basheer. Ind. J. Env. Prot. 18(4): 246-249 (1998)

[16]. Munawar, M., 1970. Limnological studies on fresh water ponds of Hyderabad, India-II, J. Hydrobiologia. 35:127-162.

[17]. Kundankar MRD, Sarwar SG, Shah MA (1995). Limnological characteristics of Hazratbal basin of Dal Lake 1992-93. Technical Report-submitted to Government of Jammu and Kashmir, India.

[18]. Reddy, K.R.P.D. Sacco, D.A Graetz, K.L. Campbell and L.R. Sinclair. 1982. Water treatment by aquatic ecosystem: Nutrient removal by reservoirs and flooded fields. J.Environmental Management, 6(3): 261-271.

[19]. Shardendu and R.S. Ambasht, 1988. Limnological studies of a rural pond and an urban tropical aquatic ecosystem: oxygen enforms and ionic strength. J.TropicalEcology. 29 (2): 98-109.

[20]. Swarnalatha, N. and A. Narasingrao, 1993. Ecological investigation of two lentic environments with reference to cyanobacteria and water pollution. Indian J.

[21]. Microbial. Ecol., 3:41-48. 